\title{
Selina Morell
}

\section{A Legal Conquest of the Arctic? China, the European Nordic Countries and Multilateralism}

\begin{abstract}
China published its first White Paper on the Arctic region in 2018, announcing its vision of integrating it as a Polar Silk Road under its Belt and Road Initiative framework. This marked the beginning of an increasingly assertive Chinese presence in the Arctic and indicated that the region has gained strategic significance in Beijing's foreign policy agenda. This master's thesis examined whether the inclusion of the Arctic in the framework of China's Belt and Road Initiative has influenced the Chinese foreign policy approach towards the Arctic countries. If the inclusion of the Arctic did indeed have an impact, this could help to assess the overall influence of the Belt and Road Initiative on China's foreign policy and gain a better understanding of how China operates in its context.
\end{abstract}

Key Words: China, Foreign Policy, Arctic, International Law, Multilateralism

Selina Morell studied European Global Studies at the Institute for European Global Studies of the University of Basel. She spent a year in Beijing (China), where she studied for one semester at the University of Tsinghua and then worked for six months as a trainee in the Political Section of the Swiss Embassy. Upon her return, she completed her master's degree in summer 2019. Today, she works as a research assistant for the Federal Department of Defence, Civil Protection and Sport. 


\section{Introduction}

Covered by thick layers of ice and snow, the Arctic region was for many years a remote place, inaccessible due to extreme climatic conditions. But these days the Arctic region is transforming; the warmer temperatures are eroding the ice and reshaping the polar landscape. In 2012, far away from the Arctic, Xi Jinping assumed leadership over China. Just one year later, he announced the launch of an ambitious infrastructure project designed to connect China more closely with Asia, Europe and Africa. This endeavor became known as the Belt and Road Initiative (yidai yilu一带 一路). In the original blueprints for the Belt and Road Initiative was no reference to the Arctic. This has recently been corrected: In 2018, Beijing published its first White Paper ${ }^{1}$ on the world's northernmost region and announced its vision of integrating it as a Polar Silk Road under the framework for the Belt and Road Initiative. Such a polar shipping route would connect Chinese ports by crossing the Arctic Ocean with northern European ports and could significantly reduce transport time compared to other more popular shipping lanes such as the southern routes through the Suez Canal and the Strait of Malacca. In the White Paper, China highlights the importance of international law and cooperation between different stakeholders for Arctic governance. It also stresses that international law grants non-Arctic countries certain rights in the region. China's argumentation is noteworthy, because so far it has generally preferred bilateral rather than multilateral strategies when expanding its influence abroad. ${ }^{2}$ Also interesting is that China has adopted a modest and hesitant stance on Arctic affairs and regularly downplayed its ambitions in the region. ${ }^{3}$ This changed with the publication of the 2018 White Paper and implies that China feels increasingly confident about taking a public role in Arctic matters. It also indicates that the region has gained strategic significance in Beijing's foreign policy agenda. ${ }^{4}$

This master's thesis examined whether the inclusion of the Arctic within the framework of China's Belt and Road Initiative has influenced the Chinese approach towards the Arctic countries. It did so by focusing on five countries as a subcategory of a total of eight Arctic states. The five Nordic countries Denmark, Finland, Iceland, Norway and Sweden were selected. They differ from the remaining Arctic countries Canada, Russia and the USA: most visibly by their size, but beyond that they also form a sub-regional group with similar languages, a common history, a comparable

\footnotetext{
1 “China's Arctic Policy,” The State Council Information Office of the People's Republic of China, January 2018, accessed on 23 April 2020, http://english.gov.cn/archive/white_paper/2018/01/26/content_281476026660336.htm.

2 Shicun Wu, Mark Valencia, and Nong Hong, eds., UN Convention on the Law of the Sea and the South China Sea (Farnham: Routledge, 2015), 283, 303; Gilbert Rozman, “Chinese Strategic Thinking on Multilateral Regional Security in Northeast Asia," Orbis 55, no. 2 (2011): 309, 311.

3 Marc Lanteigne, “'Have You Entered the Storehouses of the Snow?' China as a Norm Entrepreneur in the Arctic,” Polar Record 53, no. 2 (2017): 119; Camilla Tenna Nørup Sørensen, "China is in the Arctic to Stay as a Great Power: How China’s Increasingly Confident, Proactive \& Sophisticated Arctic Diplomacy Plays into Kingdom of Denmark Tensions,” in Arctic Yearbook 2018 - China and the Arctic Special Section, eds. Lassi Heininen and Heather Exner-Pirot, $2018,46$.

4 Nørup Sørensen, “China,” 46.
} 
level of development and similar cultural and political concepts such as the liberal-democratic social model. ${ }^{5}$ This makes them relatively well suited for comparison.

Although China's Arctic approach, as documented in the 2018 White Paper, could provide important insights into Beijing's overarching foreign policy strategy under the Belt and Road Initiative scheme, it has so far remained relatively unexplored. This thesis was an attempt to address this gap. The guiding research question was: Did China's policy approach towards the Nordic countries change as a result of the Arctic's incorporation into the Belt and Road Initiative? If it did indeed have an impact, this could help to assess the overall influence of the Belt and Road Initiative on China's foreign policy and gain a better understanding of how China operates in its context. The empirical contribution to answering this question consisted in analyzing the 2018 White Paper and extracting the main themes by means of a qualitative document analysis. As the text of the White Paper highlights international law in general and the 1982 United Nations Convention on the Law of the Sea (UNCLOS) ${ }^{6}$ in particular, the importance of these legal systems for Beijing's Arctic strategy was further explored. Based on this, the Chinese approach towards the Nordic countries was assessed by looking at three different levels: the bilateral, the multilateral as well as the scientific and non-governmental relations between China and the Nordic countries. The decision to focus on these three dimensions stems from a comprehensive examination of the relevant literature on the subject. Analyzing the dynamics within all three domains, which were also presented schematically, eventually made it possible to answer the research question. An interdisciplinary research approach was required for this thesis as a research question that would normally be considered to belong to the field of international relations, namely China's Arctic policy, was examined by taking into account aspects of international law.

\section{The Belt and Road Initiative}

With Xi's presidency China not only began to openly question Western ideas but also to promote its own concepts and institutions. ${ }^{7}$ This process has been accentuated in particular with the

\footnotetext{
5 E.g. Joanna Grzela, "Nordic Model of Subregional Co-Operation," International Studies. Interdisciplinary Political and Cultural Journal 20, no. 1 (2017): 13-29.

6 "United Nations Convention on the Law of the Sea," UN, 10 December 1982, accessed on 23 April 2020, https://www. un.org/depts/los/convention_agreements/texts/unclos/unclos_e.pdf.

7 Marc Lanteigne, Chinese Foreign Policy (New York/London: Routledge, 2016), 38; Jinghao Zhou, “China’s Core Interests and Dilemma in Foreign Policy Practice," Pacific Focus 34, no. 1 (2019): 31-54.
} 
launch of the Belt and Road Initiative. ${ }^{8}$ Xi first proposed this initiative in a speech in Kazakhstan in 2013. ${ }^{9}$ Originally, China identified five routes as components of the initiative. ${ }^{10}$ The Silk Road Economic Belt comprised three routes: One from Northwest and Northeast China to Europe and the Baltic Sea, via Central Asia and Russia; the second from Northwest China to the Persian Gulf and the Mediterranean Sea, passing through Central and West Asia; and the last from Southwest China through the Indochina Peninsula to the Indian Ocean. The 21st-Century Maritime Silk Road was envisioned with two major routes: One starting from Chinese ports, crossing the South China Sea, the Strait of Malacca, the Indian Ocean and leading to Europe; and the other extending to the South Pacific.

The overarching aim of the Belt and Road Initiative is to promote regional and global connectivity and economic growth through major infrastructure projects along these routes. So far, the initiative appears to be a collection of several interrelated elements grouped together under a broad framework rather than a clearly defined policy. ${ }^{11}$ Wang argues that China's approach to its Belt and Road Initiative is "less institutionally-focused", "not treaty-based" and "proactive". ${ }^{2}$ The initiative consists of a network of largely non-binding bilateral agreements such as memorandums of understanding. ${ }^{13}$ As it has no constituting treaty, the initiative lacks both a legal basis and an overarching institutional structure..$^{14}$ Even though the Chinese government has published several policy documents on the Belt and Road Initiative, many issues concerning the initiative remain vague and unclear, such as dispute settlement mechanisms or definitions of key concepts. ${ }^{15}$

8 Andrew Chatzky and James McBride, “China’s Massive Belt and Road Initiative," Council on Foreign Relations, 21 May 2019, accessed on 23 April 2020, https://www.cfr.org/backgrounder/chinas-massive-belt-and-road-initiative; Rush Doshi, "Hu's to Blame for China's Foreign Assertiveness?," Brookings, 22 January 2019, accessed on 23 April 2020, https://www. brookings.edu/articles/hus-to-blame-for-chinas-foreign-assertiveness; Thomas S. Eder, “China's New Foreign Policy Setup," Merics Blog - European Voices on China, 1 August 2018, accessed on 23 April 2020, https://www.merics.org/de/blog/chinasnew-foreign-policy-setup.

9 "President Xi Jinping Delivers Important Speech and Proposes to Build a Silk Road Economic Belt with Central Asian Countries," Ministry of Foreign Affairs of the People's Republic of China, 7 September 2013, accessed on 23 April 2020, https://www.fmprc.gov.cn/mfa_eng/topics_665678/xjpfwzysiesgjtfhshzzfh_665686/t1076334.shtml.

10 See: "Building the Belt and Road: Concept, Practice and China's Contribution," Office of the Leading Group for the Belt and Road Initiative, 10 May 2017, accessed on 23 April 2020, https://eng.yidaiyilu.gov.cn/wcm.files/upload/CMSydylyw/201705/201705110537027.pdf.

11 Lau Øfjord Blaxekjær, Marc Lanteigne, and Mingming Shi, "The Polar Silk Road \& the West Nordic Region," in Arctic Yearbook 2018, eds. Lassi Heininen and Heather Exner-Pirot, 2018, 437-455; Lanteigne, Chinese Foreign Policy, 11; Heng Wang, "China's Approach to the Belt and Road Initiative: Scope, Character and Sustainability," Journal of International Economic Law 22, no. 1 (March 2019): 29-55.

12 Wang, “China's Approach," 31.

13 Donald J. Lewis and Diana Moise, "One Belt One Road (“OBOR”) Roadmaps: The Legal and Policy Frameworks," in The Belt and Road Initiative. Law, Economics, and Politics, eds. Julien Chaisse and Jędrzej Górski (Leiden: Brill Nijhoff, 2018), 17-58.

14 Wang, “China’s Approach,” 29, 32.

15 Wang, “China’s Approach," 31, 49, 54f.; also see the website "Belt and Road Portal," accessed on 23 April 2020, https:// eng.yidaiyilu.gov.cn. 
The overall characteristic of the initiative is arguably its flexibility: It allows China to avoid the constraint that an institution could impose, and enables it to retain the elasticity and flexibility to adapt its approach depending on the partner or issue. ${ }^{16}$

\section{China in the Arctic}

In no way does China border the Arctic. The shortest distance between the most northern point of China (Mohe County, 漠河县 Heilongjiang Province, located at $53^{\circ} 33^{\prime}$ North) and the Arctic Circle is more than 1,400 kilometers. ${ }^{17}$ The Arctic Circle surrounds the Earth at $66^{\circ} 33^{\prime}$ North and delimits the northernmost region of the world to the South. The Arctic Ocean is the world's smallest ocean. It is surrounded by land belonging to five states, also known as the Arctic coastal states: Canada, Denmark (with Greenland), Norway, Russia and the USA (with Alaska). These countries, together with Finland, Iceland (Grimsey Island) and Sweden, are commonly known as the Arctic states, as their territory extends into the Arctic region. The region has been particularly severely affected by climate change. Due to global warming, the temperature is rising twice as fast as in the rest of the world, causing the permanent sea ice to melt. ${ }^{18}$ This development not only has serious impacts on the fragile Arctic ecosystem, but also affects the rest of the world, for example in terms of weather volatility or rising sea levels. However, a changing Arctic also offers economic opportunities. According to the US Geological Survey, about 13 percent of the world's undiscovered oil and 30 percent natural gas reserves are located above the Arctic Circle. ${ }^{19}$ The region is also rich in uranium, rare earth metals, gold, and zinc among other things. ${ }^{20} \mathrm{Up}$ to now, these resources have been almost impossible to access due to the thick ice cover and the extreme weather conditions. However, the steady retreat of sea ice makes exploration and extraction easier. Also, the Arctic shipping industry is benefiting from the warming climate. Although navigation in the waters of the Arctic Ocean was already possible, shipping remained

16 Wang, “China’s Approach,” 53f.

17 Marc Lanteigne, “China's Emerging Arctic Strategies: Economics and Institutions,” Institute of International Affairs, Center for Arctic Policy Studies, 2014, accessed on 23 April 2020, http://ams.hi.is/wp-content/uploads/2014/11/ChinasEmergingArcticStrategiesPDF_FIX2.pdf; Timo Koivurova et al., "China in the Arctic; and the Opportunities and Challenges for Chinese-Finnish Arctic Co-operation,” Institutional Repository for the Government, February 2019, accessed on 23 April 2020, http://julkaisut.valtioneuvosto.fi/bitstream/handle/10024/161371/8-2019-China_Arctic_andFinland.pdf, 52. 18 Paul Arthur Berkman, Alexander N. Vylegzhanin, and Oran R. Young, "Governing the Bering Strait Region: Current Status, Emerging Issues and Future Options,” Ocean Development \& International Law 47, no. 2 (2016): $186-217$. 19 Donald L. Gautier et al., “Assessment of Undiscovered Oil and Gas in the Arctic,” Science 324, no. 5931 (2009): 11751179; e.g. Anne-Marie Brady, China as a Polar Great Power (Cambridge: Cambridge University Press, 2017); Michael Byers, International Law and the Arctic (Cambridge: Cambridge University Press, 2013).

20 Jane Nakano, “China Launches the Polar Silk Road,” Center for Strategic and International Studies, 2 February 2018, accessed on 23 April 2020, https://www.csis.org/analysis/china-launches-polar-silk-road. 
challenging, expensive and highly dependent on the season. As the ice melts, the Arctic sea routes will increasingly become accessible and eventually more attractive. Shipping on Arctic sea routes would shorten the journey between the ports of China and Northern Europe by 40 percent compared to the current main routes through the Suez Canal or the Strait of Malacca, which translates into a reduction in transit time of 10 to 15 days. ${ }^{21}$

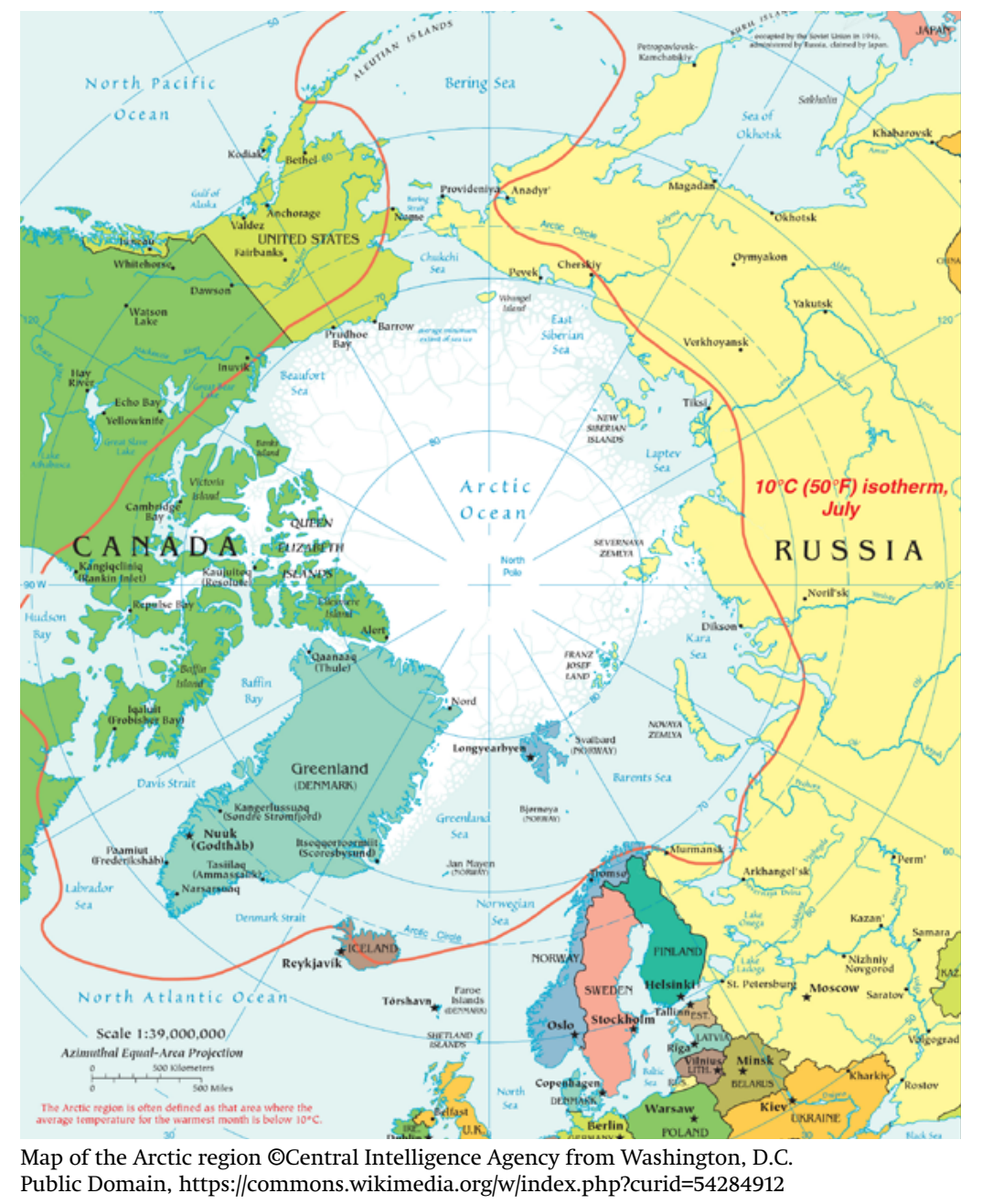

21 Michelle Wiese Bockmann, “Arctic Ship Cargoes Saving \$650,000 on Fuel Set for Record High," Bloomberg, 13 June 2012, accessed on 23 April 2020, https://www.bloomberg.com/news/articles/2012-06-13/arctic-ship-cargoes-saving-650-000-onfuel-set-for-record-high; Gang Chen, “China’s Emerging Arctic Strategy,” The Polar Journal 2, no. 2 (2012): 361; also see: Jean-Paul Rodrigue, Claude Comtois, and Brian Slack, The Geography of Transport Systems (London: Routledge, 2020). 


\section{The Arctic White Paper}

China was already active in the region prior to the publication of its 2018 White Paper. In 1992, China embarked on its first scientific research expedition in the Arctic Ocean. ${ }^{22}$ In 2013, a senior Chinese official publicly stated that China's goal of becoming a great polar power was a key component of Beijing's maritime strategy. Xi officially confirmed in 2014 China's desire to become a "polar superpower" in a speech he gave during a visit to Hobart, Australia. ${ }^{23}$ In 2017, China stated for the first time in a written document that the Arctic should be included in the Belt and Road Initiative framework as a "blue economic passage". ${ }^{24}$ Hence, the Arctic White Paper was not the start of China's Arctic policy; instead it rendered an already existing strategy for the first time visible in a comprehensive document. According to the text, Beijing's policy goals in the Arctic are: "to understand, protect, develop and participate in the governance of the Arctic, so as to safeguard the common interests of all countries and the international community in the Arctic, and promote sustainable development of the Arctic" ${ }^{25}$ The document is ten pages long and begins with a foreword describing the Arctic as a region of increasing global importance that is severely affected by global warming. It goes on to state that a changing Arctic has global implications and therefore requires global cooperation. China considers itself an "active participant, builder and contributor in Arctic affairs". ${ }^{26}$ This preface is followed by four chapters that present China's views on the legal framework for Arctic affairs, discuss its important role in the Arctic, and present its policies and positions on Arctic affairs.

A qualitative document analysis of the White Paper revealed several key themes. The most frequently mentioned topic was characterized as China's self-description. It was divided into five different sub-categories, presenting China either as: (1) involved in Arctic governance and Arctic affairs, (2) actively contributing to the common good, (3) law abiding, (4) affected by the Arctic, or as an (5) active participant in the Arctic. The second most mentioned theme captured China's description of the Arctic. The region is portrayed as being in transition due to climate change. It is stressed that this process has global implications and that the cooperation of the international community is necessary to address them. In addition to these two main topics, another theme was identified, involving the different interests China brings to the region. They were divided into four different categories:

22 Olga Alexeeva and Frédéric Lasserre, “China and the Arctic," in Arctic Yearbook 2012, ed. Lassi Heininen, $2012,81$.

23 Brady, China as a Polar Great Power, 3.

24 Brady, China as a Polar Great Power, 3; China Daily, “China Proposes 'Blue Economic Passages' for Maritime," China Daily, 21 June 2017, accessed on 23 April 2020, https://www.chinadaily.com.cn/business/2017-06/21/content_29825517.htm.

25 The State Council Information Office of the People's Republic of China, “China's Arctic Policy," 2018.

26 Ibid. 
(1) Conducting scientific research and participating in environmental protection of the Arctic China argues that scientific research is necessary to understand environmental changes in the Arctic and to identify appropriate solutions. Compared to other activities, Beijing considers scientific research as a suitable strategy for expanding its presence in the Arctic without alerting the Arctic states.

\section{(2) Participating in economic opportunities of the Arctic}

The various economic opportunities arising from a changing Arctic are mentioned far less frequently than scientific research. China, as a non-Arctic state, does not want to be perceived by the Arctic community as a greedy intruder, as a 'China threat'. However, Arctic resources, especially oil, gas and minerals, and the commercial opportunities they can offer Chinese companies are still pointed out in the White Paper. In the future, the Arctic could become an attractive energy supplier for China's growing energy needs. Reference is also made to the potential of sustainable tourism or fishing opportunities, to which, however, far less importance is attached.

(3) Securing access and participation in the development of Arctic shipping routes

China also hopes to be involved in the development of Arctic shipping and refers to Arctic sea lanes as important transport routes for future trade. They would offer China a shorter alternative to the existing routes and, in particular, would reduce its current dependence on the Strait of Malacca.

(4) Participating in Arctic affairs and governance

China is determined to be an integral part of the further development of Arctic governance and is clearly in favor of an international law framework: "China maintains the current Arctic governance system with the UN Charter and UNCLOS at its core". ${ }^{27}$ The invocation of international law occurs under the overarching narrative of the Arctic as a global sphere that requires international cooperation to address the changes caused by climate change.

27 The State Council Information Office of the People's Republic of China, “China's Arctic Policy,” 2018. 


\section{The Value of International Law for China's Arctic Strategy}

With regard to the research question, it is of interest to examine how China intends to pursue its goals and interests in the Arctic as identified in the 2018 White Paper. Apart from the frequent references to certain 'joint' actions and 'cooperations' between different actors on Arctic issues, there is no concrete statement in the document on how China intends to proceed. Nevertheless, a strategy can be derived from the wording of the White Paper: as it portrays the Arctic as a global sphere that is of equal concern to the entire world, it follows that it should also be managed by the global community. In this context, China stresses the importance of the international law regime, which currently governs the Arctic, as the best option for Arctic governance "with the UN Charter and the UNCLOS as its core", calling for "law-based governance and international cooperation" in the Arctic. ${ }^{28}$ It can thus be assumed that China seeks to improve its access to the region by strongly endorsing international law. The United Nations Conventions of the Law of the Sea (UNCLOS), which was adopted in 1982 and entered into force in 1994, is one of the most important international agreements for the Arctic region, which is in large parts dominated by the Arctic Ocean. ${ }^{29}$ UNCLOS has been ratified by all Arctic states, with the exception of the USA, which accepts the majority of the rules as customary international law. ${ }^{30}$ China ratified UNCLOS in 1996. The convention divides the ocean into several maritime zones and defines the spatial boundaries as well as rights and obligations of the various categories of actors for each zone. Much of the Arctic Ocean falls under the jurisdiction of the five Arctic coastal states. According to UNCLOS, China is considered a third state in relation to the Arctic Ocean, as it has no coastal border with its waters. UNCLOS grants third states certain rights and freedoms that are attractive in the context of China's Arctic interests. This includes rights regarding maritime navigation, marine scientific research or natural resources. While China pledges to respect "the sovereignty, sovereign rights, and jurisdiction enjoyed by the Arctic States", it also reiterates "respect [for] the rights and freedom of non-Arctic States to carry out activities in this region in accordance with the law". ${ }^{11}$ With its reference to the legal framework of UNCLOS, China not only seeks to position itself as a legitimate actor in the region, but also to make use of the advantages resulting from it. UNCLOS, which was negotiated at the international level and intends to take into account the

\footnotetext{
28 Ibid.

29 Michael Byers, “Arctic Region," in Max Planck Encyclopedia of Public International Law, last updated March 2010, accessed on 23 April 2020, https://opil.ouplaw.com; Yoshifumi Tanaka, The International Law of the Sea, (Cambridge: Cambridge University Press, 2015), 3; also see UN, "United Nations Convention on the Law of the Sea."

30 Rob Huebert, "Multilateral versus Unilateral Actions: Balancing the Needs for International Governance in the New Arctic," Position Paper for the 5th NRF Open Assembly, Anchorage, Alaska, USA, 24-27 September 2008, accessed on 23 April 2020, https://www.rha.is/static/files/NRF/OpenAssemblies/Anchorage2008/a/5th_nrf_anc_2008_huebert_multilateral_vs_unilateral_actions_arctic.pdf; Robin Churchill, "The 1982 United Nations Convention on the Law of the Sea," in The Oxford Handbook of the Law of the Sea, 2015, accessed on 18 May 2020, https://opil.ouplaw.com/view/10.1093/ law/9780198715481.001.0001/law-9780198715481.

31 The State Council Information Office of the People's Republic of China, “China’s Arctic Policy,” 2018.
} 
rights of a variety of actors in different maritime regions, presumably offers China more rights than it would receive under a regional framework negotiated among the Arctic states.

\section{China and the Nordic Countries}

An analysis of the 2018 White Paper strongly suggests that China is committed to strengthening its presence in the Arctic. In addition to highlighting the role of international law for Arctic governance, the White Paper also emphasizes the importance of relations with the Arctic states. This master's thesis examined whether such an increased interest has already become visible in China's policy towards the Nordic countries. The research findings suggest that, overall, there has been a steady increase in exchanges between China and the five countries since the new millennium. This trend affects all studied levels of relations and can be broadly divided into two main phases. When China entered the region, it joined existing institutions and concentrated on exploring the different dimensions of the Arctic and its governance. Then, in a second phase which started around 2013, China became more confident and systematic, diversified its relations and even started to promote its own platforms for Arctic cooperation. While the first phase was dominated by scientific and bilateral relations, the second phase also saw an increase in nongovernmental and multilateral cooperation.

All along, Beijing has been careful to avoid the impression that it is planning to challenge the existing governance framework in the Arctic. Scientific research was a key element in this endeavor. While spearheading China's first steps into the region, it remains at the heart of its Arctic policy. By means of research activities and newly created platforms such as the ChinaNordic Arctic Research Center (CNARC) ${ }^{32}$ China tries to legitimize its overall increasing Arctic presence. ${ }^{33}$ Over time, this approach has become more nuanced and China has acquired a considerable amount of data and advanced research technologies. It has evolved from a novice to a major scientific player in the Arctic with whom other countries are keen to collaborate. In its 2018 White Paper, China pledges that scientific research remains at the heart of its Arctic strategy and actively encourages other countries to cooperate in this domain. In addition, China has also strengthened cultural and non-state cooperation with the Nordic countries. Beijing has regularly

32 The China-Nordic Arctic Research Center (CNARC) is a network of eleven Member Institutes, five Chinese and six Nordic, which all have capacities to influence and coordinate Arctic research.

33 Camilla Tenna Nørup Sørensen, "Belt, Road, and Circle: The Arctic and Northern Europe in China's Belt and Road Initiative," in China's Belt and Road Initiative: Changing the Rules of Globalization, eds. Wenxian Zhang, Ilan Alon, and Christoph Lattemann (Cham: Springer International Publishing, 2018), 98. 
used conferences such as the Arctic Circle $^{34}$ to present its Arctic policy to the public. It has also called for a "multi-tiered Arctic cooperation framework" which would include non-Arctic states and interests, and exist on local, regional and global levels at the conference in $2015 .{ }^{35}$ The exchanges at the non-state level have proven particularly important for China's Arctic ambitions.

With the launch of the Belt and Road Initiative and China's accession as observer to the Arctic Council 2013, ${ }^{36}$ Beijing also began to expand its Arctic cooperation into new areas. Previously, its multilateral engagement in Arctic affairs has been cautious and mainly focused on securing a seat at the table and studying the functioning of Arctic governance. But now distinct efforts towards a closer sub-regional cooperation between Beijing and the Nordics have become visible, for example in the form of a so called " $5+1$ " partnership. Since the five countries have by and large supported an increased Chinese presence in the region and also proven to be valuable partners during Beijing's campaign to gain an observer role at the Arctic Council, strengthening this cooperation for the time to come made sense. China has presumably used bilateral relations as a stepping-stone into the Nordic region but prefers in future that the five countries all collaborate together as one sub-region with China.

The evolvement of a closer bilateral engagement between China and the Nordics started in the late 2000s and gradually became more pronounced. With China's application for membership in the Arctic Council in 2007, bilateral contacts to the five Nordic countries increased. Both Norway and Iceland started negotiations with Beijing on a Free Trade Agreement, and all Nordics saw high-level state visits increasing, especially before and after China's formal admission as an observer to the Arctic Council in 2013. China has conducted bilateral talks on Arctic issues with all eight Arctic countries, but its efforts towards the Nordics was particularly visible. While Chinese officials used to evade clear positioning and remained ambivalent when asked whether a Chinese Arctic strategy existed, this changed with Xi's presidency. Shortly afterwards, China presented its ideas concerning the Arctic at the Arctic Circle conference 2015. Although the Arctic White Paper was not published until three years later, it was clear from this point at the latest that

34 The Arctic Circle is an annual conference founded in 2013. It has become an important platform for Arctic and nonArctic stakeholders to debate Arctic affairs.

35 Marc Lanteigne, “Not Stopping Cold: China's Emerging Strategies in the Arctic,” Asia Centre, 16 December 2016, accessed on 23 April 2020, https://centreasia.eu/en/not-stopping-cold-chinas-emerging-strategies-in-the-arctic-marc-lanteigne-2/; Lanteigne, “Have You Entered the Storehouses of the Snow?”, 120, 124; e.g. "Keynote Speech by Vice Foreign Minister Zhang Ming at the China Country Session of the Third Arctic Circle Assembly,” Embassy of the People's Republic of China in the Republic of Iceland, 17 October 2015, accessed on 23 April 2020, http://is.china-embassy.org/eng/zbgx/t1307016.htm. 36 The Arctic Council (AC) is the main international cooperation forum for Arctic affairs, with full membership of all eight Arctic states. Other states can apply for observer seats. Switzerland has been an observer since 2017. 
China did indeed have an Arctic strategy. A lively bilateral exchange between China and all Nordic countries continued in the following years, with the exception of a seven-year diplomatic freeze between Norway and China over the award of the Nobel Peace Prize to Chinese human rights activist Liu Xiaobo. Beijing's strong stance vis-à-vis Norway is a prime example of the more assertive Chinese foreign policy. ${ }^{37}$ Compared to 1989, when the Nobel Peace Prize was awarded to the Dalai Lama, the Chinese reactions were not yet as strong. ${ }^{38}$ In the working report of the 18th Party Congress in 2012, which outlined the strategy of the Chinese Communist Party for the next five years, the Party committed itself "never to yield to external pressure" and "to protect China's legitimate rights and interests abroad". ${ }^{39}$ The case of Norway not only shows a growing Chinese confidence in its international role, it also offers the opportunity to observe its multi-channel strategy in the Arctic. When the government-to-government relationship was put on hold, China and Norway were still able to communicate via alternative channels, including multilateral formats and non-governmental platforms. China's variable, experimental and flexible foreign policy approach in the Arctic has proven to be very useful: with its harsh reaction to Norway, China sent a strong signal in defense of its core interests without compromising its long-term strategic interests in the region.

In summary, the Chinese approach to the Nordic countries has evolved considerably in the new millennium. Initially, China made substantial efforts to develop strong bilateral relations and research cooperation with all Arctic states. An analysis of the different layers of relations confirmed that over time, China has gradually expanded and diversified its engagement into cultural, multilateral and non-governmental fields. ${ }^{40}$ Without boycotting existing institutions such as the Arctic Council, China has explored ways to introduce its own institutional framework in the region, such as the China-Nordic Arctic Research Center or a " $5+1$ " partnership format with the Nordic countries. It seems that as long as the position of the observers in the Arctic Council is not upgraded, China will further strengthen or even create alternative forums for Arctic governance, where it has more influence.

37 Jerker Hellström, “China’s Political Priorities in the Nordic Countries: From Technology to Core Interests," Policy Brief of the Norwegian Institute of International Affairs 12 (2016), accessed on 23 April 2020, https://nupi.brage.unit.no/nupixmlui/handle/11250/2387468.

38 See "The Nobel Peace Prize (1989)," The Nobel Prize, accessed on 23 April 2020, https://www.nobelprize.org/prizes/ peace/1989/summary/.

39 "Full text of Hu Jintao's report at 18th Party Congress," Embassy of the People's Republic of China in the United States of America, 27 November 2012, accessed on 23 April 2020, http://www.china-embassy.org/eng/zt/18th_CPC_National_Congress_Eng/t992917.htm.

40 Nørup Sørensen, “Belt, Road, and Circle,” 98. 


\section{Conclusion}

The research question guiding this thesis was whether the Arctic's inclusion under the Belt and Road Initiative framework had an impact on China's approach towards the Nordic countries. As described above, China's relations with the Nordics have indeed expanded and become more distinct, coinciding with both the launch of the Belt and Road Initiative and China's acceptance as observer in the Arctic Council in 2013. Not only have bilateral contacts between Beijing and the five countries increased since then, but also the exchange in non-governmental, cultural and multilateral fields. When China presented its Arctic policy at the 2015 Arctic Circle conference, it anticipated many of the issues later raised in the 2018 White Paper. It can be expected that the Chinese government already considered linking the Arctic with its Belt and Road Initiative some years prior to the publication of the White Paper and aligned its foreign policy approach towards all Arctic countries accordingly. ${ }^{41}$ It is noteworthy that China has begun to address the Nordic countries as a group since 2013 (creation of China-Nordic Arctic Research Center). Nevertheless, the possibility cannot be ruled out that other factors not addressed in this thesis also had an impact on these developments. No official confirmations have been discovered that show a direct relationship between the incorporation of the Arctic in China's Belt and Road Initiative and a more distinct approach to the Nordic countries. Therefore, it can only be argued that China's increasingly comprehensive foreign policy approach towards the Nordics coincided with the inclusion of the Arctic in the Belt and Road Initiative.

In conclusion, it can be noted that there are indeed clear links between the Belt and Road Initiative, China's Arctic ambitions and its approach to the Nordic countries, with the strongest feature being that China has started to adopt a more assertive and visible Arctic policy: Only from 2013, coinciding with the introduction of the Belt and Road Initiative, did China begin to openly declare its Arctic intentions and take a more strategic approach towards their implementation, whereas previously it had regularly denied having an Arctic agenda. Along with the launch of the Belt and Road Initiative, China also explored new strategies to expand its presence in the Nordic region, such as creating non-governmental platforms or the promotion of multilateral cooperation. The research question can thus be answered by stating that China's policy approach towards the Nordic countries has indeed become more nuanced since the inclusion of the Arctic in the Belt and Road Initiative. It seems that the initiative encouraged public confirmation of China's Arctic intentions and thus stimulated both the deepening and broadening of relations with the Nordic countries. The Belt and Road Initiative could therefore be qualified as a label or a point of reference for Beijing's Arctic policy, aligning it with Beijing's broader foreign policy agenda and rendering its strategy concerning the region more assertive.

41 See: Lanteigne, "Not Stopping Cold.” 


\section{Bibliography}

\section{Documents}

Embassy of the People's Republic of China in the Republic of Iceland. "Keynote Speech by Vice Foreign Minister Zhang Ming at the China Country Session of the Third Arctic Circle Assembly." 17 October 2015, accessed on 23 April 2020. http://is.china-embassy.org/eng/zbgx/ t1307016.htm.

Embassy of the People's Republic of China in the United States of America. "Full text of Hu Jintao's report at 18th Party Congress.” 27 November 2012, accessed on 23 April 2020. http:// www.china-embassy.org/eng/zt/18th_CPC_National_Congress_Eng/t992917.htm.

Koivurova, Timo et al. "China in the Arctic; and the Opportunities and Challenges for ChineseFinnish Arctic Co-operation." Institutional Repository for the Government, February 2019, accessed on 23 April 2020. http://julkaisut.valtioneuvosto.f//bitstream/handle/10024/161371/82019-China_Arctic_andFinland.pdf.

Ministry of Foreign Affairs of the People's Republic of China. "President Xi Jinping Delivers Important Speech and Proposes to Build a Silk Road Economic Belt with Central Asian Countries." 7 September 2013, accessed on 23 April 2020. https://www.fmprc.gov.cn/mfa_eng/ topics_665678/xjpfwzysiesgjtfhshzzfh_665686/t1076334.shtml.

Office of the Leading Group for the Belt and Road Initiative. "Belt and Road Portal." Accessed on 23 April 2020. https://eng.yidaiyilu.gov.cn.

Office of the Leading Group for the Belt and Road Initiative. "Building the Belt and Road: Concept, Practice and China's Contribution." 10 May 2017, accessed on 23 April 2020. https://eng.yidaiyilu.gov.cn/wcm.files/upload/CMSydylyw/201705/201705110537027.pdf.

The Nobel Prize. “The Nobel Peace Prize (1989).” Accessed on 23 April 2020. https://www.nobelprize.org/prizes/peace/1989/summary/.

The State Council Information Office of the People's Republic of China. "China's Arctic Policy." January 2018, accessed on 23 April 2020. http://english.gov.cn/archive/white_paper/2018/01/26/ content_281476026660336.htm.

UN. "United Nations Convention on the Law of the Sea." 10 December 1982, accessed on 23 April 2020. https://www.un.org/depts/los/convention_agreements/texts/unclos/unclos_e.pdf.

\section{Literature}

Alexeeva, Olga, and Frédéric Lasserre. "China and the Arctic." In Arctic Yearbook 2012, edited by Lassi Heininen, 81-91. 2012.

Berkman, Paul Arthur, Alexander N. Vylegzhanin, and Oran R. Young. "Governing the Bering Strait Region: Current Status, Emerging Issues and Future Options." Ocean Development \& International Law 47, no. 2 (2016): 186-217. 
Blaxekjær, Lau Øfjord, Marc Lanteigne, and Mingming Shi. “The Polar Silk Road \& the West Nordic Region." In Arctic Yearbook 2018, edited by Lassi Heininen and Heather Exner-Pirot, 437-455. 2018. Brady, Anne-Marie. China as a Polar Great Power. Cambridge: Cambridge University Press, 2017. Byers, Michael. International Law and the Arctic. Cambridge: Cambridge University Press, 2013. Byers, Michael. “Arctic Region.” In Max Planck Encyclopedia of Public International Law, last updated March 2010, accessed on 23 April 2020. https://opil.ouplaw.com.

Chatzky, Andrew, and James McBride. "China's Massive Belt and Road Initiative." Council on Foreign Relations, 21 May 2019, accessed on 23 April 2020. https://www.cfr.org/backgrounder/ chinas-massive-belt-and-road-initiative.

Chen, Gang. “China’s Emerging Arctic Strategy.” The Polar Journal 2, no. 2 (2012): 358-371.

China Daily. “China Proposes ‘Blue Economic Passages’ for Maritime.” China Daily, 21 June 2017, accessed on 23 April 2020. https://www.chinadaily.com.cn/business/2017-06/21/content_29825517.htm. Churchill, Robin. "The 1982 United Nations Convention on the Law of the Sea." In The Oxford Handbook of the Law of the Sea, 2015, accessed on 18 May 2020. https://opil.ouplaw.com/ view/10.1093/law/9780198715481.001.0001/law-9780198715481.

Doshi, Rush. "Hu's to Blame for China's Foreign Assertiveness?" Brookings, 22 January 2019, accessed on 23 April 2020. https://www.brookings.edu/articles/ hus-to-blame-for-chinas-foreign-assertiveness.

Eder, Thomas S. "China's New Foreign Policy Setup." Merics Blog - European Voices on China, 1 August 2018, accessed on 23 April 2020. https://www.merics.org/de/blog/ chinas-new-foreign-policy-setup.

Gautier, Donald L. et al. "Assessment of Undiscovered Oil and Gas in the Arctic." Science 324, no. 5931 (2009): 1175-1179.

Grzela, Joanna. "Nordic Model of Subregional Co-Operation." International Studies. Interdisciplinary Political and Cultural Journal 20, no. 1 (2017): 13-29.

Hellström, Jerker. "China’s Political Priorities in the Nordic Countries: From Technology to Core Interests." Policy Brief of the Norwegian Institute of International Affairs 12 (2016), accessed on 23 April 2020. https://nupi.brage.unit.no/nupi-xmlui/handle/11250/2387468.

Huebert, Rob. "Multilateral versus Unilateral Actions: Balancing the Needs for International Governance in the New Arctic." Position Paper for the 5th NRF Open Assembly, Anchorage, Alaska, USA, 24-27 September 2008, accessed on 23 April 2020. https://www.rha.is/static/files/ NRF/OpenAssemblies/Anchorage2008/a/5th_nrf_anc_2008_huebert_multilateral_vs_unilateral_actions_arctic.pdf.

Lanteigne, Marc. “'Have You Entered the Storehouses of the Snow?' China as a Norm Entrepreneur in the Arctic." Polar Record 53, no. 2 (2017): 117-130. 
Lanteigne, Marc. Chinese Foreign Policy. New York/London: Routledge, 2016.

Lanteigne, Marc. "Not Stopping Cold: China's Emerging Strategies in the Arctic." Asia Centre, 16 December 2016, accessed on 23 April 2020. https://centreasia.eu/en/ not-stopping-cold-chinas-emerging-strategies-in-the-arctic-marc-lanteigne-2/.

Lanteigne, Marc. “China's Emerging Arctic Strategies: Economics and Institutions." Institute of International Affairs, Center for Arctic Policy Studies, 2014, accessed on 23 April 2020. http:// ams.hi.is/wp-content/uploads/2014/11/ChinasEmergingArcticStrategiesPDF_FIX2.pdf.

Lewis, Donald J., and Diana Moise. “One Belt One Road (“OBOR”) Roadmaps: The Legal and Policy Frameworks." In The Belt and Road Initiative. Law, Economics, and Politics, edited by Julien Chaisse and Jędrzej Górski, 17-58. Leiden: Brill Nijhoff, 2018.

Nakano, Jane. "China Launches the Polar Silk Road." Center for Strategic and International Studies, 2 February 2018, accessed on 23 April 2020. https://www.csis.org/analysis/ china-launches-polar-silk-road.

Nørup Sørensen, Camilla Tenna. "Belt, Road, and Circle: The Arctic and Northern Europe in China's Belt and Road Initiative." In China's Belt and Road Initiative: Changing the Rules of Globalization, edited by Wenxian Zhang, Ilan Alon, and Christoph Lattemann, 98-113. Cham: Springer International Publishing, 2018.

Nørup Sørensen, Camilla Tenna. “China Is in the Arctic to Stay as a Great Power: How China's Increasingly Confident, Proactive \& Sophisticated Arctic Diplomacy Plays into Kingdom of Denmark Tensions." In Arctic Yearbook 2018 - China and the Arctic Special Section, edited by Lassi Heininen and Heather Exner-Pirot, 43-58. 2018.

Rodrigue, Jean-Paul, Claude Comtois, and Brian Slack. The Geography of Transport Systems. London: Routledge, 2020.

Rozman, Gilbert. "Chinese Strategic Thinking on Multilateral Regional Security in Northeast Asia." Orbis 55, no. 2 (2011): 298-313.

Tanaka, Yoshifumi. The International Law of the Sea. Cambridge: Cambridge University Press, 2015. Wang, Heng. "China's Approach to the Belt and Road Initiative: Scope, Character and Sustainability." Journal of International Economic Law 22, no. 1 (March 2019): 29-55.

Wiese Bockmann, Michelle. "Arctic Ship Cargoes Saving \$650,000 on Fuel Set for Record High." Bloomberg, 13 June 2012, accessed on 23 April 2020. https://www.bloomberg.com/news/ articles/2012-06-13/arctic-ship-cargoes-saving-650-000-on-fuel-set-for-record-high.

Wu, Shicun, Mark Valencia, and Nong Hong, eds. UN Convention on the Law of the Sea and the South China Sea. Farnham: Routledge, 2015.

Zhou, Jinghao. “China's Core Interests and Dilemma in Foreign Policy Practice.” Pacific Focus 34, no. 1 (2019): 31-54. 